\title{
Periodontal disease characterization in dogs with normal renal function or chronic renal failure
}

\author{
Caracterização da doença periodontal em cães com insuficiência renal \\ crônica ou função renal normal
}

\section{Glenda Ramalho Barbudo-Selmi ${ }^{1}$ Marileda Bonafim Carvalho ${ }^{2}$ André Luis Selmi ${ }^{1}$ Silvio Emílio Cuevas Martins ${ }^{3}$}

\section{ABSTRACT}

The purpose of this study was to evaluate periodontal disease (PD) in dogs with chronic renal failure $(C R F)$ and to compare it to $P D$ in dogs with normal renal function (NRF). Twelve dogs with CRF and 24 dogs with NRF, all presenting dental pocket formation, were compared. In all dogs, serum creatinine, blood urea nitrogen, urine specific gravity and total red and white blood cells were determined. A complete oral examination was also performed including evaluation of bacterial plaque, gingivitis, gingival recession, pocket, calculus, dental mobility, dental loss, and ulcers. These data were used to calculate plaque index (PI), gingival index (GI) and periodontal destruction index (PDI). PD was graded as mild, moderate or severe based on the results. Mild, moderate or severe PD was observed in dogs with NRF, whereas dogs with CRF presented either mild or severe PD. Dogs with $N R F$ showed higher involvement of the maxillary teeth, whereas dogs with CRF showed a higher involvement of the mandibular teeth. Plaque index was significantly higher in dogs with NRF. It was concluded that lesion distribution and periodontal disease progression may be altered in dogs with $C R F$, and gingival inflammatory response differs in dogs with $N R F$ and CRF regarding to the stage of periodontal disease.

Key words: periodontal disease, chronic renal failure, dogs.

\section{RESUMO}

O objetivo deste estudo foi comparar a doença periodontal $(D P)$ em cães com insuficiência renal crônica
(IRC) e cães com função renal normal (FRN). Doze animais com IRC e 24 com FRN, apresentando formação de bolsa periodontal foram comparados. Em todos os animais, realizouse determinação do nível sérico de uréia e creatinina, da densidade urinária e dos valores do hemograma e leucograma. o exame da cavidade oral constou da avaliação do grau de placa bacteriana, gengivite, recessão gengival, bolsa periodontal, cálculo dentário, mobilidade e perda dentária e presença de úlceras. Os dados foram utilizados para determinação do índice de placa dentária (IP), índice gengival $(I G) e$ índice de destruição periodontal (IDP). A DP foi classificada como sendo discreta, moderada ou severa baseada nos achados. Cães com FRN apresentaram DP variando de discreta a severa, enquanto cães com IRC apresentaram DP discreta ou severa. Cães com FRN apresentaram maior envolvimento dos dentes maxilares enquanto animais com IRC apresentaram maior acometimento dos dentes mandibulares. $O$ IP foi significativamente maior em cães com FRN. Concluiuse que a distribuição e progressão da DP podem apresentar-se de forma alterada em cães com IRC, e que a resposta inflamatória gengival difere em cães com IRC ou FRN, dependendo do grau de DP presente.

Palavras-chave: doença periodontal, insuficiência renal crônica, cães.

\section{INTRODUCTION}

Periodontal disease (PD) is the most common oral disease in dogs as it may affect both

\footnotetext{
${ }^{1}$ Médico Veterinário. Mestre. Aluno do curso de Pós-graduação em Cirurgia Veterinária. Universidade Estadual Paulista (UNESP), Faculdade de Ciências Agrárias e Veterinárias de Jaboticabal (FCAVJ). Professor. Universidade de Brasília, Faculdade de Agronomia e Medicina Veterinária. Campus Darcy Ribeiro, CP 04508, 70910-970, Asa Norte, Brasília, DF. E-mail: selmi@unb.br Autor para correspondência.

${ }^{2}$ Médico Veterinário, Doutor, Professor Assistente. Universidade Estadual Paulista/ Faculdade de Ciências Agrárias e Veterinárias de Jaboticabal. Departamento de Clínica e Cirurgia Veterinária. Rod. Prof. Paulo Donato Castelane, s/n. 14870-000 Jaboticabal/SP. ${ }^{3}$ Médico Veterinário. Aluno do curso de Pós-graduação em Cirurgia Veterinária, FCAVJ, UNESP.
} 
health and quality of life. It is considered a factor that predisposes patients to bacteremia (CUTCHER et al., 1971; CALVERT et al., 1985), however, clinical manifestation of bacteremia is not well correlated with the causative agent or it may not be clinically apparent (CALVERT et al., 1985), although, in dogs, kidney disease is considered a consequence of low-grade bacteremia associated with PD (DE BOWES et al., 1996).

Periodontal lesions are characterized by a progressive and inflammatory condition of the periodontal tissue that includes the gingiva, the cementum, and the alveolar supporting bone and periodontal ligament. The initial factor is the bacterial plaque accumulation in the dental surface and violation of the gingival sulcus integrity (EISNER, 1989a $\mathrm{a}^{-1}, \mathrm{~b}$; CARRANZA \& RAPLEY, 1997). The polymorphonuclear leukocyte (PMN) is important in defending the periodontium against plaque infection (KHOCHT, 1996), and patients presenting PMN defects or low number of PMN often develop severe periodontal disease (MIYASAKY, 1991). Chronic renal failure (CRF) is associated with impairment in PMN function (HAAG-WEBER \& HÖRL, 1993). As it occ ${ }^{1}$ urs to human beings, dogs will have gingival defense problems when they are under serious stress, such as renal failure (EISNER, 1989a).

Several studies have evaluated the relation between periodontal disease and chronic renal failure in humans. In $\operatorname{dogs}$, PD has been related to morphological changes in renal glomeruli and interstitium (DEBOWES et al., 1996) Evaluation of periodontal status in patients before and after renal allotransplatantion showed that, although bacterial plaque accumulation was similar among systemically healthy individuals with periodontitis, and patients with CRF and periodontitis, patients with CRF had suppression of gingival inflammation. There is evidence that uremic state inhibits inflammatory response, but patients are still able to have a partial response to bacterial challenge (YAMALIK et al., 1991). However, others have observed that patients with CRF had significantly higher plaque index score than the control group, but no significant differences could be found among the groups with regard to mean periodontal index score, pocket depth, bleeding score or gingival index score (RAHMAN et al., 1992). Dental and periodontal conditions of normal children and children with CRF have been evaluated. The CRF group showed less gingivitis and higher calculus index than the control group, but plaque index was similar for both groups (JAFFE \& ROBERTS, 1986).

Increased tooth mobility is present in periodontitis as a consequence of reduction of supporting bone structure. There is periodontal attachment migration towards the apex of the tooth and erosion of the alveolar bone (EISNER, 1989a). In a study conducted in dogs under experimental nutritional hyperparathyroidism and periodontitis, osteopenia did not result in increased tooth mobility or gingivitis in the absence of plaque (SVANBERG et al., 1973).

There is some controversy between reported findings in humans. Results are influenced by a number of interfering factors related to the patients' hygienic care. This is not a problem for most dogs, as only a small percentage of the canine population has dental care. Thus, the purpose of this report is to describe periodontal findings in dogs with naturally acquired chronic renal failure (CRF) in comparison to periodontal disease of, otherwise, healthy dogs.

\section{MATERIAL AND METHODS}

Subjects in the study consisted of 12 dogs ( 5 females and 7 males) between the ages of 3 and 13 years that were referred to Nephrology Unit at Veterinary Teaching Hospital (VTH) - FCAV-UNESP, Jaboticabal, Brazil. The control group consisted of 24 systemically healthy dogs (13 females and 11 males) with ages varying from 3 and 13 years, referred to the Dentistry Unit at the VTH for dental care (first-time in life). Body weight for dogs in both groups ranged from 2,1 to $15,8 \mathrm{~kg}$. Information related to the general health status and renal function were retrieved from the patient's record. The CRF dogs' group included patients presenting creatinine level $7.43 \pm 5.65 \mathrm{mg} \mathrm{dl}^{-1}$, BUN level $111.04 \pm 43.23 \mathrm{mg} \mathrm{dl}^{-1}$, urine specific gravity $1.014 \pm 0.005, \mathrm{RBC} 4.15 \pm 1.82 \times 10^{6} \cdot \mathrm{ml}^{-1}$ and WBC $9.30 \pm$ $5.86 \times 10^{3} \cdot \mathrm{ml}^{-1}$. None of them had undergone dental treatment before. The control group included patients presenting creatinine level $1.23 \pm 0.29 \mathrm{mg} \mathrm{dl}^{-1}$, BUN level $18.24 \pm 5.50 \mathrm{mg} . \mathrm{dl}^{-1}$, urine specific gravity $1.035 \pm 0.012$, RBC 6.25 $\pm 0.92 \times 10^{6} \cdot \mathrm{ml}^{-1}$ and WBC $8.56 \pm 1.81 \times 10^{3} \cdot \mathrm{ml}^{-1}$. To be included in the NRF or CRF group, dogs should have well characterized pocket formations, the hallmark for true irreversible periodontal disease (EISNER, 1989a). Also, all dogs presented a mesocephalic head type.

All oral examinations were carried out by a single examiner and included evaluation of bacterial plaque, gingivitis, gingival recession, pocket, calculus, dental mobility, dental loss, and ulcers. The examination included all teeth present.

The extent of pocket formation (from the free gingival margin to the bottom of the pocket) and 
the extent of the recession (from the free gingival margin to the cement-enamel junction) were measured on facial aspects of teeth by using a periodontal millimeter probe. The measurements were rounded to the nearest whole millimeter. Teeth mobility was assessed by digital pressure and used as an indicator for supporting bone structure loss and determination of the periodontal destruction index.

All data were collected in an appropriate form. The number of present teeth was recorded. Plaque Index (PI) and Gingival Index (GI) were scored using the systems described by LÖE (1967), however, only facial aspects of teeth were considered. A modified Periodontal Destruction Index (PDI) was used, where: PDI $=$ Pocket depth $(\mathrm{mm})+$ Recession $(\mathrm{mm})$, total number of existing teeth (OSHRAIN et al., 1979).

Periodontal disease was graded on the basis of the worst teeth affected, according to pocket depth. Periodontitis was graded as slight (pockets $>2$ and $<3 \mathrm{~mm}$ ), moderate (pockets $>3$ and $<5 \mathrm{~mm}$ ) and severe (pockets $>5 \mathrm{~mm}$ ). This study considered the normal sulcus in dogs as being <2mm, as described by GORREL \& BIERER (1999).

Results were expressed as means and standard deviation. Comparisons between groups were made using Student's t test.

\section{Results}

Twenty-four dogs with normal renal function were studied and classified as presenting a slight $(29.2 \%)$, moderate $(37.5 \%)$ or severe $(33.3 \%)$ degree of PD. Twelve dogs with CRF were classified as having a slight $(58,3 \%)$ or severe $(41.7 \%)$ degree of PD.

Bacterial plaque, gingivitis and calculus formation in maxillary and mandibular teeth of dogs of both groups with initial periodontitis was present from the canine to the molar teeth bilaterally. However, dogs with NRF showed a higher involvement of the maxillary teeth, whereas dogs with CRF showed a higher involvement of the mandibular teeth.

Marked gingival recession was observed in maxillary teeth of dogs of both groups, with dogs in NRF group presenting a bilateral involvement from the $3^{\text {rd }}$ incisor distal to the molars teeth; dogs in CRF group had involvement of the whole maxillary dental arcade. Only dogs in NRF group presented gingival recession of the mandibular canine teeth.

Maxillary arcades of dogs of GI with severe periodontitis presented a higher degree of bacterial plaque over the canine teeth, and dental calculus and gingivitis from the canine to the premolars teeth bilaterally, whereas dogs of GII showed a higher involvement of the $4^{\text {th }}$ maxillary premolars and $1^{\text {st }}$ maxillary molars. In dogs of GII these findings were more evident and evenly distributed along the mandibular teeth than that of dogs of GI.

Gingival recession in dogs of GII was more evident on the $4^{\text {th }}$ maxillary premolars and $1^{\text {st }}$ maxillary molar teeth, whereas dogs of GI presented it over the maxillary canine and molars teeth. Mandibular canine and premolars teeth were equally involved in both groups.

Tooth mobility was observed only in dogs with severe periodontitis. Dogs of GI and GII presented equal mobility of maxillary premolar and molar teeth. Mobility of mandibular incisors was observed in dogs with CRF, whereas dogs with normal renal function presented uniform mobility distribution along the mandibular teeth.

Periodontal indexes of dogs with NRF and CRF are depicted in table 1 . Table 2 presents periodontal indexes of $\operatorname{dog} s$ with $\mathrm{NRF}$ or CRF according to stage of periodontal disease.

Table 1 - Periodontal status of healthy dogs and dogs with chronic renal failure.

\begin{tabular}{|c|c|c|c|}
\hline Group & CRF & NRF & Student's \\
\hline Variable & $\bar{X}$ & $\bar{X}$ & T test \\
\hline Number of patients & 12 & 24 & 36 \\
\hline Age (years) & $3-13$ & $3-13$ & - \\
\hline Periodontal Destruction Index & $0.63 \pm 0.69$ & $0.65 \pm 1.04$ & 0.95 \\
\hline Plaque Index & $0.64 \pm 0.50$ & $0.93 \pm 0.57$ & 0.14 \\
\hline Gingival Index & $0.83 \pm 0.59$ & $0.92 \pm 0.62$ & 0.70 \\
\hline Retention Index & $0.78 \pm 0.45$ & $0.88 \pm 0.55$ & 0.60 \\
\hline
\end{tabular}

$\mathrm{CRF}$ - chronic renal failure, NRF - normal renal function, $\bar{X}$ - means, SD - standard deviation 
Table 2 - Periodontal status of healthy and chronic renal failure dogs, with slight and severe periodontitis.

\begin{tabular}{|c|c|c|c|c|c|c|c|c|}
\hline Group & CR & $\mathbf{F}$ - SL & NRF & $\mathbf{F}-\mathbf{S L}$ & Student's & CRF - S & NRF - S & Student's \\
\hline Variable & $\bar{X}$ & SD & $\bar{X}$ & SD & T test & $\bar{X}$ & $\bar{X}$ & T test \\
\hline $\mathbf{N}$ & & 7 & & 7 & 14 & 5 & 8 & 13 \\
\hline PDI & 0.22 & \pm 0.15 & 0.21 & \pm 0.13 & 0.90 & $1.20 \pm 0.75$ & $1.46 \pm 1.55$ & 0.74 \\
\hline PI & 0.43 & \pm 0.18 & 0.84 & \pm 0.33 & $0.01^{*}$ & $0.94 \pm 0.66$ & $1.10 \pm 0.60$ & 0.66 \\
\hline GI & 0.62 & \pm 0.47 & 0.68 & \pm 0.25 & 0.78 & $1.34 \pm 0.60$ & $1.20 \pm 0.82$ & 0.76 \\
\hline RI & 0.64 & \pm 0.47 & 0.72 & \pm 0.27 & 0.69 & $0.98 \pm 0.39$ & $1.23 \pm 0.78$ & 0.52 \\
\hline
\end{tabular}

* Significant $(P<0.05)$. PDI - periodontal destruction index, PI - plaque index, GI - gingivitis index, RI - retention index. CRF - chronic renal failure, NRF - normal renal function, SL - slight periodontitis, $\mathrm{S}$ - severe periodontitis

Oral mucosa ulcers and tissue necrosis were observed in one dog of GII with severe periodontitis. Some dogs of GI were classified as having a moderate degree of periodontitis (pockets $<3$ or $\geqslant 5 \mathrm{~mm}$ ) and no comparison with dogs with CRF could be made.

\section{DISCUSSION}

Pocket depth was used as criteria for PD stage distribution. Considering gingivitis, dental plaque, calculus formation and gingival recession followed by an aggravating condition of PD, two important events occur. First, it becomes evident that loss of dental-supporting structures results in increased mobility and tooth loss; and second, the progression of PD is related to lesion distribution. At early stages, a few areas are preserved and then involvement of maxillary and mandibular incisors $\left(\mathrm{M}_{\mathrm{x}} \mathrm{I}\right.$ and $M_{b} I$, respectively) and aggravation of the mandibular arcade takes place. Initially, there is an increase in dental plaque accumulation in the maxillary arcade, with a marked involvement of $M_{x} I$ followed by involvement of $\mathrm{M}_{\mathrm{b}} \mathrm{I}$. Gingivitis follows at a later stage (e.g. moderate PD) around $\mathrm{M}_{\mathrm{x}} \mathrm{I}$. When PD reaches an advanced stage (e.g. severe PD), gingivitis worsens around $\mathrm{M}_{\mathrm{x}} \mathrm{I}$ and becomes evident around $\mathrm{M}_{\mathrm{b}} \mathrm{I}$. Changes associated with pocket deepening are not accompanied by calculus distribution along teeth surface.

In dogs with CRF, PD progression occurred in a different way, confirming the hypotheses raised by several authors (SÖDERHOLM et al., 1974; LARATO, 1975; OSHRAIN et al, 1979; TOLLEFSEN \& JOHANSEN, 1985a,b; JAFFE \&"ROBERTS, 1986; MIYASAKI, 1991; YAMALIK et al., 1991; RAHMAN et al., 1992; HAAG-WEBER \& HÖRL, 1993; KHOCHT, 1996). At early stages, dental plaque accumulation is much more evident involving the mandibular teeth, including the $\mathrm{M}_{\mathrm{b}} \mathrm{I}$, while the $\mathrm{M}_{\mathrm{x}} \mathrm{I}$ present both plaque accumulation and gingivitis. In severe periodontitis there is a generalized increase in dental plaque accumulation along the mandibular arcade, with a corresponding increase in gingival inflammation. These findings corroborate those of other authors that observed a greater degree of gingivitis in uremic patients (TOLLEFSEN \& JOHANSEN, 1985a), and that of YAMALIK et al. (1991) who reported that in CRF there is no abolishment of inflammatory gingival response, although a diminished response might occur under immunosuppressive therapy. However, this is not in accordance with another study where a lower degree of gingivitis was observed in patients with CRF, and this finding was attributed to an inadequate inflammatory response (JAFFE \& ROBERTS, 1986).

Analysis of plaque index (PI), gingivitis index (GI), retention index (RI) and periodontal destruction index (PDI) between groups were not significant. However, all indexes presented a higher value in dogs with NRF when compared to dogs with CRF. When separately comparing data regarding slight and severe periodontitis, PI was significantly higher in dogs with NRF compared to dogs with CRF for slight periodontitis. Studies have shown that hypersalivatory dogs presented a faster rate for accumulation of dental plaque when compared to dogs with normal saliva production, indicating the importance of saliva in plaque formation (EISNER, 1989a). Thus, when considering the fact that patients with renal failure have a decreased salivation (POLZIN \& OSBORNE, 1995), a higher PI in dogs with NRF could be associated with normal saliva secretion.

It has been demonstrated that bacteremia could result from trauma to bacterial-laden mucosal surfaces (CUTCHER et al., 1971; CALVERT et al., 1985), and that kidney disease could originate from chronic low-grade bacteremia associated with PD (DEBOWES et al., 1996). Direct relation between PD and the degree of renal function was not possible in this study, as CRF could have originated from PD or from several 
different causes. Although the study of DEBOWES et al. (1996) demonstrated a significant relationship between PD and morphological changes in the kidneys, myocardium and hepatic parenchyma, the authors were not capable of inferring whether those changes would have occurred in spite of PD, as many systemic healthy patients may have PD, as demonstrated in this study. This is also corroborated by previous findings in dogs, which show no relationship between bacteremia and bacterial endocarditis in dogs with cardiovascular infections (CALVERT et al., 1985).

In severe periodontitis, despite the fact that no significant differences were observed, dogs with CRF presented a higher GI than dogs with NRF, as observed in uremic patients (TOLLEFSEN \& JOHANSEN, 1985a). Additionally, studies have shown that inflammatory gingival response to dental plaque changes during renal failure (KHOCHT, 1996). However, we have observed that GI did not differ between groups in dogs with slight $\mathrm{PD}$, presenting a conflicting finding. Deficient or diminished function of PMNs appears to be related to progression of severe PD (MIYASAKI, 1991), but recent studies have shown that the possible effects of PMNs on periodontal condition of patients with CRF are not of sufficient magnitude (KHOCHT, 1996). Such controversy could be elucidated if different evaluation criteria were used, as the one described herein, where PD is related to pocket depth.

In our study, indexes criteria were used as recommended by LÖE (1967) and OSHRAIN et al. (1979). The results are much more elucidative when PD staging is considered. Moreover, it is more practical, faster and costs less when compared to the standard protocol of bone loss evaluation by means of radiography in dogs (HARVEY \& EMILY, 1993).

Index-based analysis implicates in considering the severity of variables studied. It also considers the total number of teeth involved in PD in a single animal. When one considers only the presence or absence of lesions, for each single tooth, the result is different and lead to distinct conclusions. When evaluating these variables, and not taking into account the indexes, it is possible to verify that CRF is associated with progression of PD and aggravation of affected periodontal areas.

Initial oral evaluation or those performed along a time interval in human beings may vary not only due to PD, CRF, transplantation and hemodialysis, but also because of dental hygiene (TOLLEFSEN \& JOHANSEN, 1985a). Some patients may vigorously perform dental hygiene before examination, or may not perform it at all on occasions when stressful conditions such as hemodialysis or transplantation are eminent. These variables may negatively interfere in clinical trials with human beings, and could explain some divergences among authors. By studying dogs, as done herein, it is possible to evaluate PD without any interference from different behavioral or dental hygiene methods, and as the dog may naturally acquire both $\mathrm{PD}$ and renal failure, it may represent an interesting experimental model.

\section{ACKNOWLEDGMENTS}

The authors would like to thank the FAPESP for financial support of this project.

\section{REFERENCES}

CALVERT, C.A.; GREENE, C.E.; HARDIE, E.M. Cardiovascular infections in dogs: epizootiology, clinical manifestations, and prognosis. Journal of the American Veterinary Medical Association, Schaumburg, v.187, n.6, p.612-616, 1985

CARRANZA, A.F.; RAPLEY, J.W. Patologia periodontal. In: CARRANZA, A.F.; NEWMAN, M.G. Periodontia clínica. 8.ed. Rio de Janeiro : Guanabara, 1997. p.229-362.

CUTCHER, J.L. et al. Control of bacteremia associated with extraction of teeth. II. Oral Surgery, Oral Medicine and Oral Pathology, Saint Louis, v.31, n.5, p.602-605, 1971.

DE BOWES, L.J. et al. Association of periodontal disease and histopathologic lesions in multiple organs from $45 \mathrm{dogs}$. Journal of Veterinary Dentistry, Champaign, v.13, n.2, p.57-60, 1996.

EISNER, E.R. Periodontal disease in pets: the pathogenesis of a preventable problem. Veterinary Medicine, Lenexa, v.84, n.1, p.97-104, 1989a

EISNER, E.R. Treating moderate periodontitis in dogs and cats. Veterinary Medicine, Lenexa, v.84, n.8, p.768, 1989 b.

GORREL, C.; BIERER, T.L. Long term effects of a dental hygiene chew on the periodontal health of dogs. Journal of Veterinary Dentistry, Champaign, v.16, n.3, p.109-113, 1999.

HAAG-WEBER, M.; HÖRL, W.H. Uremia and Infection: Mechanisms of impaired cellular host defense. Nephron, Basel, v.63, n.3, p.125-131, 1993.

HARVEY, C.E.; EMILY, P.P. Small animal dentistry. St. Louis : Mosby, 1993. p.89-114.

JAFFE, E.C.; ROBERTS, G.J. Dental findings in chronic renal failure. British Dentistry Journal, Hants, v.160, n.1, p.1820, 1986.

KHOCHT, A. Periodontitis associated with chronic renal failure: a case report. Journal of Periodontology, Chicago, v.67, n.11, p.1206-1209, 1996. 
LARATO, D.C. Uremic stomatitis: report of a case. Journal of Periodontology, Chicago, v.46, n.12, p.731-733, 1975.

LÖE, H. The gingival index, the plaque index and the retention index systems. Journal of Periodontology, Chicago, v.38, p.610-616, 1967.

MIYASAKI, K.T. The neutrophil: Mechanisms of controlling periodontal bacteria. Journal of Periodontology, Chicago, v.62, p.761-774, 1991.

OSHRAIN, H.I.; MENDER, S.; MANDEL, I.D. Periodontal status of patients with reduced immunocapacity. Journal of Periodontology, Chicago, v.50, n.4, p.185-188, 1979.

POLZIN, D.J.; OSBORNE, C.A. Pathophysiology of renal failure and uremia. In: OSBORNE, C.A.; FINCO, D.R. Canine and feline nephrology and urology. Baltimore : Williams \& Wilkins, 1995. Cap.12, p.335-367.

RAHMAN, M.M.; ÇAGLAYAN, F.; RAHMAN, B. Periodontal health parameters in patients with chronic renal failure and renal transplants receiving immunosuppressive therapy. Journal of the Nihon University School of Dentistry, Tókio, v.34, n.5, p.265-272, 1992.
SÖDERHOLM, G.; LYSELL, L.; SVENSSON, A. Changes in the jaws in chronic renal insufficiency and haemodialysis. Report of a case. Journal of Clinical Periodontology, Copenhagen, v.1, n.2, p.36-42, 1974.

SVANBERG, G.; LINDHE, J.; HUGSON, A. Effect of nutritional hyperparathyroidism on experimental periodontitis in dog. Scandinavian Journal of Dental Research, Göteborg, v.81, n.5, p.155-162, 1973.

TOLLEFSEN, T.; JOHANSEN, J.R. Periodontal status in patients before and after renal allotransplantation. Journal of Periodontal Research, Copenhagen, v.20, p.227-236, 1985a.

TOLLEFSEN, T.; JOHANSEN, J.R. The periodontal status of prospective and renal transplant patients. Comparison with systemically healthy subjects. Journal of Periodontal Research, Copenhagen, v.20, p.220-226, 1985b.

YAMALIK, N. et al. The histological investigation of gingival from patients with chronic renal failure, renal transplants, and periodontitis: A light and electron microscopic study. Journal of Periodontology, Chicago, v.62, n.12, p.737744, 1991. 